\title{
Alternative Splicing in Plant Genes: A Means of Regulating the Environmental Fitness of Plants
}

\author{
Xudong Shang, Ying Cao and Ligeng Ma * \\ College of Life Sciences and Beijing Key Laboratory of Plant Gene Resources and Biotechnology for Carbon \\ Reduction and Environmental Improvement, Capital Normal University, Beijing 100048, China; \\ 2160801011@cnu.edu.cn (X.S.); ying.cao@cnu.edu.cn (Y.C.) \\ * Correspondence: ligeng.ma@cnu.edu.cn; Tel.: +86-10-6890-7339
}

Academic Editor: Akila Mayeda

Received: 24 December 2016; Accepted: 10 February 2017; Published: 20 February 2017

\begin{abstract}
Gene expression can be regulated through transcriptional and post-transcriptional mechanisms. Transcription in eukaryotes produces pre-mRNA molecules, which are processed and spliced post-transcriptionally to create translatable mRNAs. More than one mRNA may be produced from a single pre-mRNA by alternative splicing (AS); thus, AS serves to diversify an organism's transcriptome and proteome. Previous studies of gene expression in plants have focused on the role of transcriptional regulation in response to environmental changes. However, recent data suggest that post-transcriptional regulation, especially AS, is necessary for plants to adapt to a changing environment. In this review, we summarize recent advances in our understanding of AS during plant development in response to environmental changes. We suggest that alternative gene splicing is a novel means of regulating the environmental fitness of plants.
\end{abstract}

Keywords: gene expression; alternative splicing; transcriptional regulation; environmental fitness; plant

\section{Introduction}

Nearly $90 \%$ of the protein-coding genes in plants are interrupted genes; that is, the coding region is divided by introns. Therefore, an essential step in gene expression is the removal of introns through the splicing of precursor mRNA transcripts (pre-mRNAs) [1,2]. Splicing is performed by the spliceosome, a large ribonucleoprotein (RNP) complex that assembles around splice sites in the introns of a pre-mRNA molecule and then removes the introns catalytically through sequential phosphodiester transfer reactions [3-6]. During splicing, $5^{\prime}$ and $3^{\prime}$ splice sites, which mark the beginning and end of each intron in a pre-mRNA, together with the branch site (a consensus sequence-containing region located near the $3^{\prime}$ splice site) are recognized by the uridine (U)-rich small nuclear RNPs (snRNPs) U1, U2, U4, U5, and U6, and a multitude of non-snRNP splicing factors, including U2AF65, U2AF35, and serine/arginine-rich (SR) proteins [7]. Together, these factors form one of the most complex machines in cells, the spliceosome, which performs the two transesterification reactions that are necessary to excise introns and join together the selected exons [8]. Spliceosome assembly at an intron is a highly ordered and dynamic process that is guided by consensus sequences [9].

Genome-wide transcriptome mapping has revealed that the extent of alternative splicing (AS) in plants ranges from $42 \%$ to $61 \%$ [10-12]. In AS, a single pre-mRNA can produce more than one mRNA through the use of alternative splice sites. AS is a regulated process that increases the diversity of an organism's transcriptome and proteome. It can regulate transcript levels by producing new unstable mRNA isoforms, which can be degraded by nonsense-mediated decay (NMD) $[13,14]$. AS can also produce alternate functional mRNAs encoding protein isoforms with differences in subcellular localization, stability, or function by changing or completely removing functional domains 
via the introduction of a premature termination codon (PTC), intron retention, or alternative $3^{\prime}$ or $5^{\prime}$ splice site selection [15]. New isoforms of transcripts, proteins, or even polypeptides may act as dominant-negative inhibitors of the authentic proteins by means of interactions with dimerization partners [16]. Therefore, the precision and efficiency of alternative splicing are critical factors in gene function. Given their sessile nature, plants must adapt immediately to environmental changes to ensure their survival. Here, we summarize recent advances in our understanding of AS as it relates to the environmental fitness of plants.

\section{Ambient Temperature and Vernalization-Mediated Flowering}

Higher plants go through numerous developmental transitions during their life cycle. Among these transitions, the floral transition is the best studied. Analyses of the regulation of flowering in Arabidopsis have demonstrated how environmental signals and endogenous cues may be integrated to create a developmental switch in plants [17]. In recent decades, key regulators of flowering time and their targets have been described in Arabidopsis.

To determine the right moment for flowering, plants utilize many environmental signals, including photoperiod (day length), light quality, biotic/abiotic stresses, and temperature. Temperature in particular has been shown to have tremendous effects on the timing of flowering; in the vernalization response of Arabidopsis thaliana, plants quantitatively sense long-term cold exposure and epigenetically store this information to regulate flowering time [18]. In contrast, our knowledge of the genetic and molecular mechanisms that regulate flowering time in response to small changes in ambient temperature (i.e., the thermosensory pathway) is limited. Evidence indicates that AS plays an important role in the ability of plants to measure ambient temperatures and to integrate this external information with endogenous signals to regulate flowering $[19,20]$.

In A. thaliana, the central mechanism of accelerated flowering in response to prolonged cold exposure is repression of the transcription of FLOWERING LOCUS C (FLC), which encodes a MADS-box transcription factor and negative regulator of flowering. MADS-domain transcription factors have important roles in the development of plants throughout their life cycle, including flowering [21]. FLC expression is regulated by several pathways: the FRIGIDA pathway, which up-regulates FLC expression; the autonomous pathway, which down-regulates $F L C$ expression; the vernalization pathway, a cold-induced epigenetically silenced FLC expression during winter [22]. COOLAIR is a non-coding RNA, which fully encompasses FLC in the antisense direction [23]. The level of FLC expression is associated with the level of COOLAIR splicing isoforms. Class I COOLAIR variants, which links with low level of $F L C$ expression, uses a small intron and polyadenylation at a proximal region. Class II COOLAIR variants, linking with high level of FLC expression, is associated with a large intron and polyadenylation at a distal region [24,25]. PRP8 is a conserved and central component of the spliceosome, mutation in PRP8 influences the splicing efficiency of COOLAIR introns, which reduces COOLAIR proximal poly(A) site usage [25]. Furthermore, the splicing of COOLAIR plays an important role in the adaptive evolution of flowering time in Arabidopsis thaliana accessions. SNP259, a single natural intronic polymorphism located in $F L C$, can significantly change COOLAIR splicing, further affecting FLC expression and flowering time. SNP259 is a major contributor to the natural variation in FLC haplotypes [26]. In addition, long noncoding RNA not only acts as AS target, but is also involved in regulating AS. AS competitor long noncoding RNA (ASCO-lncRNA) can hijack nuclear speckle RNA-binding protein (NSR) to affect the splicing patterns of several NSR-regulated mRNA targets that specifically promote lateral root growth in Arabidopsis [27].

SHORT VEGETATIVE PHASE (SVP) and FLOWERING LOCUS M (FLM) also belong to MADS-box proteins. FLM is subject to temperature-dependent AS. Two splice variants, FLM- $\beta$ and $F L M-\delta$, which differ in the incorporation of either the second or third cassette exon and can be translated into two protein isoforms, have been detected in the Columbia-0 accession [28]. Interestingly, the ratio of $F L M-\beta$ to $F L M-\delta$ changes in response to deviations in ambient temperature [29]. FLM- $\beta$ is down-regulated in response to increases in temperature, suggesting that FLM- $\beta$ and FLM- $\delta$ have 
different roles in the control of flowering by ambient temperature [30]. However, the biological functions of $F L M-\beta / \delta$ are unclear.

Recent discoveries have revealed a combinatorial role for FLM and SVP in flowering, with ambient temperature modulating both factors in different ways. $F L M-\beta$ and $F L M-\delta$ encode proteins that interact antagonistically with SVP. FLM- $\beta$ was demonstrated to bind DNA only in the presence of SVP in vitro; however, FLM- $\delta$ could not bind DNA in vitro, thus, it prevented SVP from binding the target DNA in a dose-dependent manner $[19,20]$. These results indicate that FLM- $\beta$ and $-\delta$ protein levels mirror those of their corresponding mRNAs, which are regulated by ambient temperature changes. These results suggest a working model in which FLM- $\delta$ acts as a dominant-negative isoform of FLM that renders the SVP-FLM- $\beta$ complex inactive, thereby indirectly promoting the flowering transition at elevated temperatures $[19,20]$.

Similar to FLM/MAF1, the MADS AFFECTING FLOWERING 2 (MAF2) gene, which is closely related to $F L M$, is subjected to temperature-dependent AS to produce two isoforms, var1 and var2. Only MAF2 var1 encodes a functional full-length MIKC-type MADS-domain transcription factor that is sufficient to repress flowering when overexpressed in A. thaliana accession Ll-2, which does not express MAF1-MAF4 [31,32]. Similar to FLM, the repressive isoform var1 is regulated by temperature-dependent AS. In addition, plants overexpressing MAF2 var2 are not early flowering, suggesting that var2 does not act as a dominant-negative protein, as is the case for FLM- $\delta$.

In summary, AS functions as a "thermometer" in plants, measuring moderate changes in ambient temperature (Figure 1). Although the effects of different splice variants (e.g., FLM- $\beta / \delta$ and MAF2 var1/2) on flowering are clear, the exact mechanism by which temperature-dependent AS modulates the onset of flowering is poorly understood. Furthermore, ambient temperature-responsive splicing factors that regulate AS have not yet been discovered.

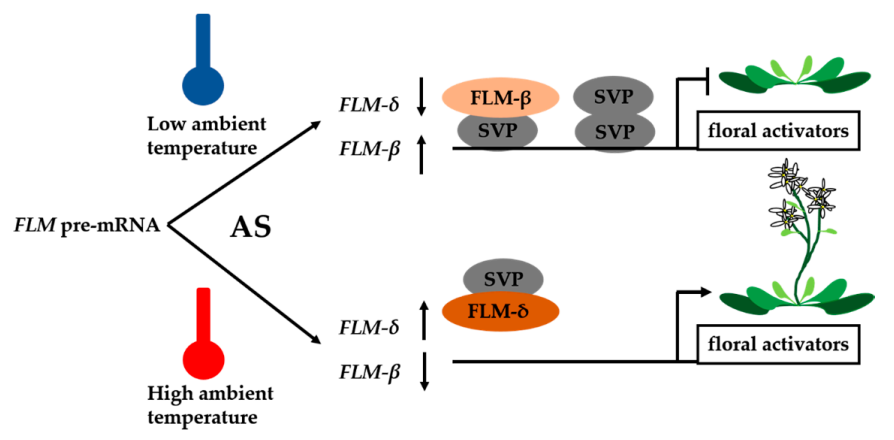

Figure 1. Model of the temperature-dependent FLOWERING LOCUS M (FLM) function. At low temperature, SHORT VEGETATIVE PHASE (SVP) can form homodimer or interact with FLM- $\beta$ to form heterodimer to repress floral activators. When the temperature increased, the alternative splicing of FLM pre-mRNA increased the level of $F L M-\delta$. FLM- $\delta$ proteins compete with the FLM- $\beta$ to form FLM- $\delta$-SVP complex and repress the transcription of floral activator genes. AS, alternative splicing.

\section{The Circadian Clock in Plants}

The circadian clock, an endogenous timekeeper that generates rhythms with an approximately $24 \mathrm{~h}$ period, plays critical roles in diverse aspects of plant growth and development, and coordination of biological processes with daily environmental cycles [33,34]. It was reported that the expression of about $30 \%$ of the genes in Arabidopsis genome is controlled under the circadian clock [35-37].

The circadian clock is composed of several interlocking regulatory feedback loops in Arabidopsis [38]. CIRCADIAN CLOCK-ASSOCIATED1 (CCA1) and LATE ELONGATED HYPOCOTYL (LHY) repress the expression of TIMING OF CAB EXPRESSION 1 (TOC1) through direct binding to its promoter $[39,40]$. Recent studies have shown that TOC1 binds directly to specific morning elements in the promoters of CCA1 and LHY as a transcriptional repressor and suppresses CCA1/LHY 
accumulation [41-43]. In the morning loop, CCA1 and LHY directly activate the expression of PSEUDO RESPONSE REGULATOR7 (PRR7) and PRR9, two homologs of TOC1; in turn, PRR7 and PRR9 suppress the expression of CCA1 and LHY [44,45]. In the evening loop, TOC1 represses the expression of GIGANTEA (GI), while the expression of TOC1 is up-regulated by GI [46]. The proteins encoded by EARLY FLOWERING (ELF)3, ELF4, and LUX ARRHYTHMO form the so-called evening complex (EC), which suppresses the expression of TOC1, GI, and PRR9 [47,48]. Together, these interlocking central, morning, and evening loops form the basis of the circadian clock in Arabidopsis.

To date, most studies of the regulation of the circadian clock in both animals and plants have focused on the transcriptional and post-translational regulatory mechanisms. The roles of AS in the regulation of the circadian clock have been uncovered recently. Through whole-genome sequencing and RT-PCR analysis, two $C C A 1$ transcripts, $C C A 1 \alpha$ and $C C A 1 \beta$, have been reported $[49,50]$. $C C A 1 \beta$, an alternatively spliced variant of $C C A 1$ that retains the fourth intron, is conserved in the dicot tree Populus and the monocot grasses Oryza and Brachypodium, suggesting its functional importance; in addition, $C C A 1 \beta$ is accumulated under high light conditions but decreased in cold conditions. The roles of these variants in regulating the circadian clock have been recently reported [50].

CCA1 $\beta$ has a dimerization domain, like CCA $1 \alpha$, but lacks the N-terminal DNA-binding MYB motif $[50,51]$. Homodimerization and heterodimerization of CCA1 $\alpha$ and LHY are required for these proteins to regulate circadian rhythms [52]. The splice variant CCA1 $\beta$, as a dominant regulator, represses CCA $1 \alpha /$ LHY heterodimerization by competing with CCA1 $\alpha$ and LHY to form nonfunctional CCA $1 \alpha /$ CCA $1 \beta$ and CCA1 $\beta /$ LHY heterodimers, revealing the regulatory role of the AS of CCA1 in circadian rhythms [50]. Recent research showed that SR45 bound specifically to the retained CCA1 intron in vitro, suggesting that SR45 is involved in the regulation of intron splicing [53].

Protein arginine methyltransferase 5 (AtPRMT5) has been shown to regulate circadian period in Arabidopsis. PRMT5, a type II protein arginine methyltransferase, catalyzes the methylation of diverse non-histone proteins, including components of the spliceosome (e.g., AtSmD1 and AtLSm4); the reduction in the methylation levels of SmD1 and LSm4 causes the splicing defects in genes involved in multiple biological processes, including the circadian clock, probably by regulating $5^{\prime}$ splice site recognition [54,55]. The circadian period is lengthened by mutations in AtPRMT5 [56]. Atprmt5 exhibits defects in the AS of PRR7 and PRR9, resulting in lengthening of the circadian period; thus, AS regulates the circadian clock at the post-transcriptional level [54]. LSM4 and LSM5, which encode core components of the spliceosomal U6 snRNP complex, can be methylated by PRMT5. $l s m 4$ and $l s m 5$ plants display a long period phenotype as well as aberrant splicing of several clock genes, including CCA1 and TOC1, but not PRR9, suggesting that the effect of PRMT5 on the circadian clock is not simply due to its effect on LSM4.

Besides PRMT5, which indirectly affects the splicing of clock genes, the involvement of splicing factors in the circadian clock control has been demonstrated [57,58]. The Ski-interacting protein (SKIP) is the first splicing factor that is required for the regulation of circadian clock. SKIP is a conserved component of the precursor RNA processing (Prp)19 complex, a sub-complex of spliceosome complexes B and C, which are required for catalysis of the first and second steps in pre-mRNA splicing in yeast and human cells [59]. The mutation of SKIP has dramatic effects on the circadian clock in Arabidopsis. For example, the skip-1 mutant exhibits a temperature-sensitive long period phenotype and changes in light input and clock sensitivity to resetting by light [57]. Consistent with the role of SKIP in mammals (SKIP) and yeast (Prp45), AtSKIP encodes a conserved SNW domain-containing protein. AtSKIP co-localizes in nuclear speckles with the spliceosome components U1-70k [60] and SR45 [61], and it associates with the pre-mRNAs of clock genes, including PRR7 and PRR9 [57,62]. Defects in the AS of PRR7 and PRR9 partially contribute to the lengthened period of the clock in the skip-1 mutant [57,62].

Similarly, the RNA-binding protein SPLICEOSOME TIMEKEEPER LOCUS 1 (STIPL1) is homologous to the spliceosomal proteins Ntr1p in Saccharomyces cerevisiae and TFP11 in humans, which are required for spliceosome disassembly. The mutation of STIPL1 increased levels of the intron-retained variants of CCA1, LHY1, TOC1, PRR9, and GI, and this may contribute to the observed 
clock phenotype [58], indicating the requirement of STIPL1 for the correct splicing of clock genes. The spliceosomal snRNP assembly factor GEM NUCLEAR ORGANELLE ASSOCIATED PROTEIN 2 (GEMIN2) plays an important role in modulating the effect of low temperatures on the splicing of certain pre-mRNAs (e.g., TOC1 and PRRs), and it attenuates the effects of temperature on the period length of the circadian clock [63]. Recently, another regulator, SICKLE (SIC), a conserved proline/serine-rich protein found in nuclear foci, emerged as a link between the circadian clock, temperature compensation, and AS. The sic-3 mutant exhibits defects in the clock genes, such as arrhythmic or low-amplitude expression of several core circadian clock genes under cool ambient temperature cycles, but no defect was observed under light-dark entrainment. Additionally, sic exhibits increased levels of splice variants of $L H Y, E L F 3, C C A 1$, and PRR7. Further, compared to wild type, sic has a broader range of temperature conditions under which these splice variants occur, particularly at cool temperatures [64].

The above mentioned results indicated that AS is essential for normal functioning of the circadian clock in Arabidopsis (Figure 2). The circadian oscillator plays an important role in the interaction between plants and their environment by synchronizing endogenous biological activities, biochemical processes, and behavior with daily environmental changes in the day-night cycle. Interlocking transcription-translation feedback loops form the basis for regulation of the clock. Recent studies also showed that AS is required for the regulation of the circadian clock in Drosophila, and Neurospora, suggesting that AS, a key step in post-transcriptional gene expression regulation, is a general mechanism of clock regulation. However, the detailed molecular mechanisms of AS that regulate the circadian clock, how the circadian clock regulates AS in response to external environment changes, and how endogenous developmental processes affect the circadian clock via AS are far from clear. The spliceosome has been described as a sea of proteins; indeed, more than 200 components have been purified from the mammalian spliceosome [65]. However, only a small proportion of them have been functionally characterized. Future studies should identify the roles of splicing factors or AS in the regulatory network of the circadian clock.

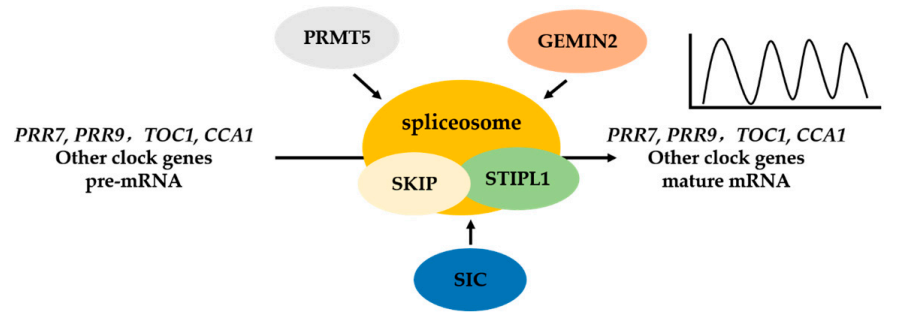

Figure 2. Components of spliceosome and splicing regulators mediate alternative splicing of the circadian clock genes in Arabidopsis. The Ski-interacting protein (SKIP), SPLICEOSOME TIMEKEEPER LOCUS 1 (STIPL1) are components of the spliceosome. Protein arginine methyltransferase 5 (PRMT5), GEM NUCLEAR ORGANELLE ASSOCIATED PROTEIN 2 (GEMIN2), SICKLE (SIC) are regulators of spliceosome. These splicing factors are involved in regulating the circadian clock through alternative splicing of clock genes pre-mRNAs, such as PRR7, PRR9, TOC1, CCA1. These studies suggest that pre-mRNA splicing, a post-transcriptional gene expression regulation, is a new means of circadian clock regulation.

\section{Abiotic Stress Responses}

Given their sessile nature, plants are dependent on their immediate environment for survival, and the growth and development of plants are heavily affected by environmental cues [66-68]. AS in response to abiotic/biotic stresses has a wide range of effects on plants, and most genes involved in plant stress responses are said to be regulated by AS.

Heat shock (HS) transcription factors (Hsfs) are key regulators of the response of plants to heat stress; thus, HS-induced transcriptional regulation has been extensively studied [69]. Recently, 
AS has been shown to be critical for the HS-inducible expression of HsfA2. HsfA2 contains a single 324-nucleotide intron that is fully spliced at $22{ }^{\circ} \mathrm{C}$ to generate the full-length $H s f A 2$ transcript [70]. Moderate heat $\left(37^{\circ} \mathrm{C}\right)$ activates a 31-nucleotide cryptic miniexon within the $H s f A 2$ intron to generate a splice variant HsfA2-II. HsfA2-II contains a PTC within the miniexon, thus is degraded by NMD. The third splice variant $H s f A 2-I I I$ is generated through the cryptic $5^{\prime}$ splice site in the intron, which is activated by extreme heat $\left(42-45^{\circ} \mathrm{C}\right)$, while HsfA2-II decreases [71]. HsfA2-III encodes a truncated protein, S-HsfA2, which localizes to the nucleus; it contains an Hsf helix-turn-helix DNA binding motif, and can bind to HS elements in the HsfA2 promoter, generating a positive autoregulatory loop that controls HsfA2 expression through AS.

The maize gene $Z m r b o h B$ is required for the production of reactive oxygen species (ROS) in response to avirulent pathogens and several abiotic stresses. ROS levels need to be finely tuned to prevent toxicity, and to support their activity as signaling molecules [72,73]. ZmrbohB has two alternatively spliced isoforms, ZmrbohB- $\delta$ and ZmrbohB- $\beta$ (which retains intron 11); these isoforms carry a PTC that probably leads to NMD in response to several abiotic stimuli, including cold, heat, ultraviolet radiation, and salt stress [74].

The splicing of some transcription factor genes also undergo AS under stressful conditions. For example, two splice variants of OsDREB2B are differentially expressed in response to heat and drought stresses in rice [75]. The transcript of OsDREB2B1 is more abundant under normal growth conditions; it contains a 53-base pair exon 2 insertion in the mature mRNA that introduces an open reading frame shift. In plants exposed to high temperature stress, OsDREB2B2, in which exon 2 is spliced out in the mature mRNA, dominates. Through AS, rice can produce dehydration-responsive element-binding protein2 (DREB2B) rapidly, independentally of transcriptional activation. A similar mechanism of AS has been described for WDREB2 in wheat, and for its orthologs HvDRF1 in barley and $Z m D R E B 2 A$ in maize [76-78].

The splicing of non-protein coding RNA transcripts is an emerging area of study, specifically in plant systems. The first example of environmental changing-induced AS is from the expression of miR400. miR400 is located in the intron of a protein-coding gene. Heat stress-induced AS of a transcript that contains this intron results in decreased production of the mature miRNA by affecting miRNA processing. The altered miR400 level in turn changes the level of its host transcript [79].

A number of RNA processing factors is associated with plant responses to abscisic acid (ABA). RNA binding motif protein 25 (RBM25) binds to the last intron in HAB1 pre-mRNA and regulates its AS to produce two splice variants: HAB1.1 and HAB1.2. HAB1.1 contains four exons and encodes a protein that interacts with and inhibits the kinase activity of SnRK2.6/OST1, switching ABA signaling off. HAB1.2 contains four exons and the last intron; it encodes a truncated protein lacking 105 amino acids at the C-terminal end. HAB1.2 is able to interact with SnRK2/OST1, but it cannot inhibit the protein's kinase activity; thus, ABA signaling remains on [80,81]. Therefore, the alternative splicing of $H A B 1$ pre-mRNA results in the production of two variants of $H A B 1$ mRNA, and translates to two functional antagonistic proteins in ABA signaling pathway. Thus, AS for genes encoding the components of ABA signaling pathway is critical for ABA function.

In addition to the induction of AS by environmental stress, evidence shows that spliceosomal proteins play crucial roles in the proper function of abiotic stress response pathways in Arabidopsis. SR proteins bind splicing signal sites and intronic and exonic splicing enhancer/silencer sequences through interactions with multicomponent splicing factors to determine splice site selection and where the spliceosome assembles. SR45 is an SR-like protein with two SR domains. The mutation of SR45 in Arabidopsis produces pleiotropic developmental defects, including altered leaf and flower morphology, delayed root growth, late flowering, [82], and defects in ABA and glucose signaling [83], resulting in dramatic genome-wide changes in the AS of pre-mRNAs [84].

Interestingly, AS generates two SR45 transcripts. SR45.1 contains a 21-nucleotide sequence that is absent from $S R 45.2$ due to the selection of an alternative $3^{\prime}$ splice site in intron 6 in $S R 45.1$ [85,86]. These two splice variants encode similar proteins, differing by only eight amino acids, which include 
several putative phosphorylation sites. Remarkably, complementation studies showed that SR45.1 rescued the floral but not the root phenotype in sr $45-1$, while $S R 45.2$ could complement the root growth defect observed in sr45-1 [86]. By contrast, AS of SR45 does not likely play a role in sugar signaling, as both splice forms were able to rescue the glucose hypersensitivity of the sr45-1 [84].

\section{Biotic Stress Responses}

Plants are often attacked by a variety of pathogens, including fungi, viruses, and bacteria, as well as by insects and nematodes. Thus, plants have developed a number of defense mechanisms against these pathogens during evolution. Resistance $(R)$ proteins are crucial proteins for plant defense against pathogens. The AS of $R$ genes plays crucial roles in the regulation of plant defense responses at the post-transcriptional level [87-89].

Most $R$ genes in plants encode the nucleotide-binding site (NBS) leucine-rich repeat (LRR) proteins which are characterized by containing NBS and LRR domains [90-94]. The coding region of most TIR-NBS-LRR genes contains three or four extrons. Among them, the first exon encodes the TIR domain, the second exon encodes the NBS domain, and the remaining exons encode the LRR region. Alternative isoforms have been observed from many TIR-NBS-LRR genes, including tobacco (Nicotiana tabacum) $N$ and Bs4, Arabidopsis RAC1, RPS4, RPS6, RPP5, and SNC1 [95-101]. The tobacco N gene confers resistance to the tobacco mosaic virus (TMV). AS produces two transcript variants: a short NS transcript encoding the functional $\mathrm{N}$ protein and a long $N L$ transcript containing an alternative 70-nucleotide exon within the third intron that leads to a frame shift and PTC. Thus, the long NL transcript encodes a truncated protein that lacks most of the LRRs. Before infection, NS is prevalent. At $4-8 \mathrm{~h}$ after TMV infection, however, the level of NL is 60-fold higher than that of NS. Plants overexpressing only NS show little resistance to TMV. Thus, the alternative exon in intron 3 is required for full resistance to TMV in tobacco [102].

Similar to the tobacco N gene, Arabidopsis RPS4 confers resistance to Pseudomonas syringae pv. tomato strain DC3000 (DC3000) expressing AvrRps4; however, this resistance is regulated by AS. Due to premature stop codons, the alternatively spliced isoforms encode no or a reduced number of LRRs. Transformation of the genomic sequence lacking intron 2 or 3 driven by the RPS4 promoter into rps4 revealed that the deletion any of the introns was sufficient to abolish the function of RPS4. Therefore, AS of RPS4 is required for Arabidopsis to resistance to DC3000 [99,103]. AS produces different transcript isoforms, and thus produces protein variants which may contain a combination of the TIR and NBS domains or only the TIR domain [104].

Screening for suppressors of the gain-of-function mutant suppressor of npr1-1 constitutive1 (snc1) in Arabidopsis identified a series of modifier Of $\operatorname{snc1}(\mathrm{MOS})$ genes, some of which encode subunits of a splicing-associated protein complex, including modifier Of snc1, 4 (MOS4), cell division cycle 5 (CDC5), and pleiotropic regulatory locus 1 (PRL1) [105]. Interestingly, their homologs in humans and yeast are components of the Prp19 complex, which is essential for catalytic activation of the spliceosome [106]. MOS4-associated complex (MAC)3A and MAC3B, two closely related proteins with sequence homology to Prp19, were identified by immunoprecipitation followed by mass spectrometry. Reported defects in the AS of SNC1 in mos4, $c d c 5$, and mac3a mac3b demonstrate that MAC mediates the AS of $R$ genes and influences plant defenses [107]. MAC5A is also involved in pathogen defense [108]. The MAC5A counterpart in humans is RNA-binding motif protein 22, which interacts with U6 small nuclear RNA and pre-mRNA and participates in splicing. This suggests that MAC5A is also involved in pre-mRNA splicing in Arabidopsis [109]. All the results above suggest that AS is required for plants in response to biotic stresses.

\section{Splicing Factors or Transcriptional Co-Regulators in Plants}

Many splicing factors are not only components of the spliceosome that participate in pre-mRNA splicing, they can also interact with other proteins to form complexes that regulate different biological 
processes. Recent research has demonstrated that some plant splicing factors play an important role in transcriptional regulation.

SKIP is a spliceosome component that interacts with the pre-mRNAs of circadian clock genes and is essential for regulating their AS [57]. Still, SKIP is not involved in the splicing of sense or anti-sense FLC pre-mRNA. However, the levels of mature and unspliced FLC mRNAs were found to be obviously repressed in skip-1. Yeast two-hybrid screening showed that SKIP interacts with ELF7, a component of the Paf1 complex (Paf1c), which is conserved from yeasts to humans and plants [110,111]. The Paf1c is required for the recruitment of histone modification factors and chromatin remodeling factors, and for small RNA-mediated gene silencing [112,113]. In Arabidopsis, the Paf1c represses the floral transition by activating FLC transcription [110]. The Paf1c modulates the expression of FLC clade genes at the transcriptional level by binding to and mediating H2B mono-ubiquitination (H2Bub1) and the tri-methylation of lysine 4 on histone H3 (H3K4me3) of FLC clade gene chromatin in Arabidopsis [111]. The results of a chromatin immunoprecipitation assay suggested that SKIP and the Paf1c are required for the H2Bub1 and H3K4me3 of FLC clade gene chromatin [111], supporting the proposed interaction between SKIP and the Paf1c in the regulation of flowering in Arabidopsis. Therefore, SKIP appears to be involved in two complexes. It can function as a splicing factor that ensures the accurate splicing of pre-mRNAs on a genome-wide scale by interacting with other components of the spliceosome, and as a transcriptional activator that interacts with other transcriptional regulators (e.g., the Paf1c) to regulate the expression of specific genes at the transcriptional level [62,111] (Figure 3). However, whether the function of these two complexes is independent or coupled through SKIP is unknown [111].

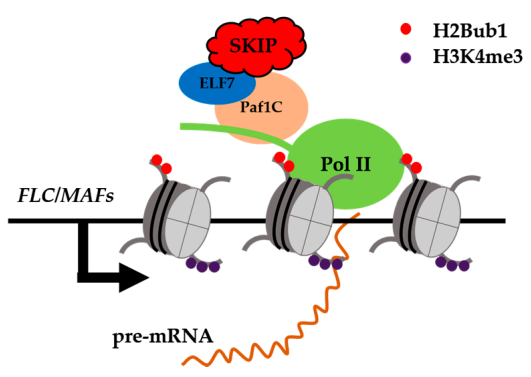

Figure 3. SKIP interacts directly with EARLY FLOWERING 7 (ELF7) to promote FLC/MADS AFFECTING FLOWERING (MAFs) transcription. SKIP is a transcriptional activator that interacts with the ELF7, a component of the Pol II associated factor 1 complex (Paf1c), to regulate the levels of H2B monoubiquitination (H2Bub1) and H3K4 trimethylation (H3K4me3) in FLC clade gene chromatin. SKIP represses the floral transition mainly by activating the transcription of FLOWERING LOCUS C (FLC) clade genes in Arabidopsis.

RNA-mediated transcriptional silencing is an evolutionary conserved mechanism that is required for the maintenance of genome stability, repression of transposable elements, and regulation of gene expression in eukaryotes [114-116]. The methylation of DNA in transposons and in other DNA repeats is conserved from plants to animals. In A. thaliana, an RNA-directed DNA methylation (RdDM) pathway directs de novo DNA methylation [116]. By screening for suppressors of Repressor of Silencing 1 (ros1), a series of genes involved in RdDM has been identified [117,118]. Interestingly, some of these suppressors are splicing factors, including SR45 [119], ZOP1 [120], STA1 [121], PRP31 [122], and RDM16 [123].

ZOP1, an N-terminal C2H2-type ZnF and OCRE domain-containing protein, promotes DNA polymerase (Pol) IV-dependent small interfering RNA (siRNA) accumulation, DNA methylation, and transcriptional silencing. High-throughput mRNA sequencing analysis demonstrated that ZOP1 works as a pre-mRNA splicing factor, and it associates with several typical splicing machinery components. Immunofluorescence assays demonstrated that ZOP1 overlaps with the Cajal bodies and is partially co-localized with NRPE1 and DRM2 [120]. 
STA1 is a PRP6-like splicing factor, and is predominantly required for the accumulation of siRNAs that depend on both Pol IV and Pol V. The sta1 mutation results in partially reduced levels of Pol V-dependent RNA transcripts. High-throughput mRNA sequencing and RT-PCR analysis demonstrated that sta1 has no effect on the transcription of RdDM genes, suggesting that STA1 has a direct role in the RdDM pathway. Immunolocalization assays suggested that STA1 signals were exclusively present in the Cajal bodies and overlapped with that of AGO4 in most nuclei [121].

RDM16 encodes a homolog of yeast pre-mRNA-splicing factor 3 (Prp3), a component of the $\mathrm{U} 4 / \mathrm{U} 6 \mathrm{snRNP}$, which is required for pre-mRNA splicing in yeast. RNA-Seq analysis showed that 308 intron retention events were observed in $r d m 16$ compared to that in wild-type plants, which confirmed that RDM16 is required for pre-mRNA splicing in plants. The $r d m 16$ mutant exhibits morphological defects and is hypersensitive to ABA signal and salt stress. However, RDM16 is likely to be directly involved in the RdDM pathway as $r d m 16$ does not exhibit the defection in the splicing of other RdDM genes tested [123].

As mentioned above, SR proteins play important roles in constitutive splicing and AS, and in other aspects of mRNA metabolism. The Arabidopsis SR45 protein was first identified in a yeast two-hybrid screen as an interacting partner of U1-70K [124], a component of the U1 snRNP known in animals to initiate spliceosome assembly by binding $5^{\prime}$ pre-mRNA splice sites $[125,126]$. SR45 can also interact with the spliceosomal factor U2AF35, which is involved in $3^{\prime}$ splice site recognition $[9,127]$. Moreover, SR45 has been found to interact with three U5 snRNPs [128] as well as with several other Arabidopsis SR proteins; namely, SCL33, RSZ21, SR30, SR34, and SR34a [124,128,129]. Two other reported SR45-interacting proteins in Arabidopsis are the spliceosomal component SKIP [57], which confers salt stress tolerance [130], and CACTIN, an essential nuclear factor required for embryogenesis [131]. The sr45-1 mutant exhibits delayed flowering under both long- and short-day conditions and can be rescued by vernalization. FLC, a key flowering repressor, is up-regulated in sr45-1. Recently, proteomics was used to identify the SIN3-associated protein 18 (SAP18) and its two partners, the RNA-binding protein SR45 and the SAP-domain protein ACINUS. SAP18 is a component of the SIN3-histone deacetylase complex, which is required in humans to enhance the SIN3-mediated repression of transcription [132]. SAP18 has also been linked to RNA processing and degradation and is a subunit of the conserved apoptosis- and splicing-associated protein complex. Together with SR45 and ACINUS, SAP18 is required for VAL1-mediated FLC silencing [133] (Figure 4).

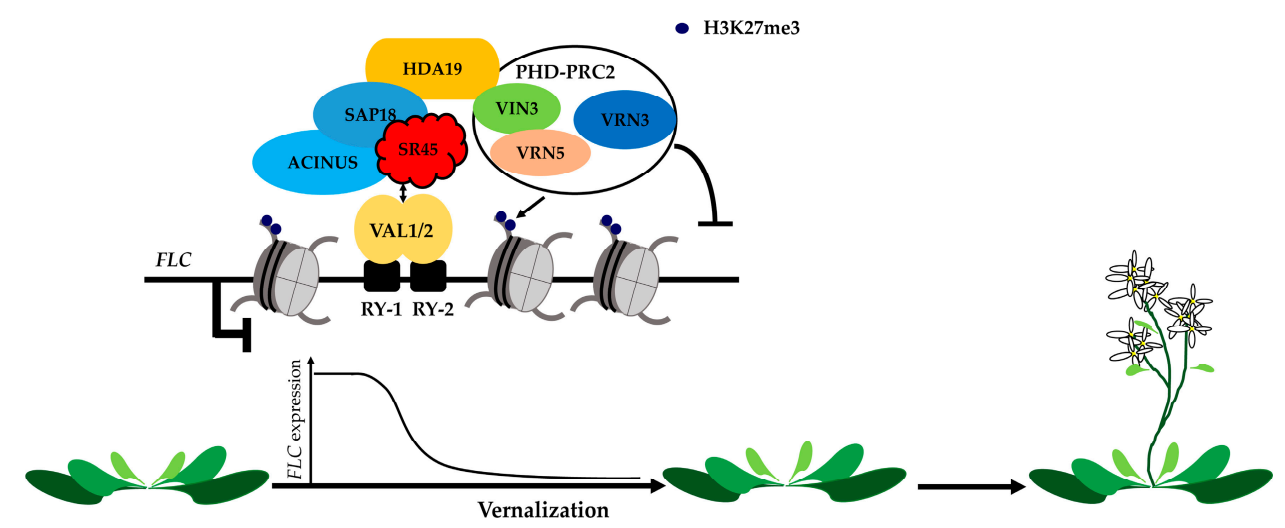

Figure 4. Apoptosis- and splicing-associated protein (ASAP) complex is involved in Polycomb silencing of FLC expression during vernalization. During vernalization, VAL1/2 bind the RY-1/2 cis-elements in the first intron of $F L C$, interact with components of the conserved ASAP complex, which consists of SIN3-associated protein 18 (SAP18), ACINUS and SR45, and further recruit PHD-PRC2. This transcriptional repression complex triggers histone deacetylation in FLC chromatin and leads to FLC transcriptional silencing in a sequence specific manner during vernalization. HDA: histone deacetylase. PRC2: polycomb repressive complex 2. VIN3: vernalization insensitive 3. VRN: vernalization. VAL: viviparous1/ABI3-like. 
Recently, genome-wide identification of RNA targets of SR45, using RNA immunoprecipitation (RIP) followed by high-throughput sequencing (RIP-seq), uncovered the unexpected roles of this RNA binding protein in RNA processing. More than 4000 RNAs are associated with SR45 directly or indirectly. Interestingly, 340 SR45-associated RNAs belong to the intronless genes. Based on the results from the genome-wide analysis, it seems that SR45 does not work as a splicing factor in regulating mRNA processing of intronless gene [134].

Therefore, some splicing factors, including SKIP, SR45, ZOP1, STA1, and RDM16, work as both a splicing factor and a transcriptional co-regulator. Whether these factors couple the transcriptional and post-transcriptional regulation of gene expression requires further investigation.

\section{Perspectives and Conclusions}

Previous studies focused on the role of gene expression in plants in response to environmental changes at the transcriptional level. However, accumulating evidence supports the idea that the post-transcriptional regulation of gene expression plays critical roles in the response of plants to environmental changes as well. AS is a key process in post-transcriptional gene regulation; thus, it is a new means of regulating the environmental fitness of plants (Figure 5).

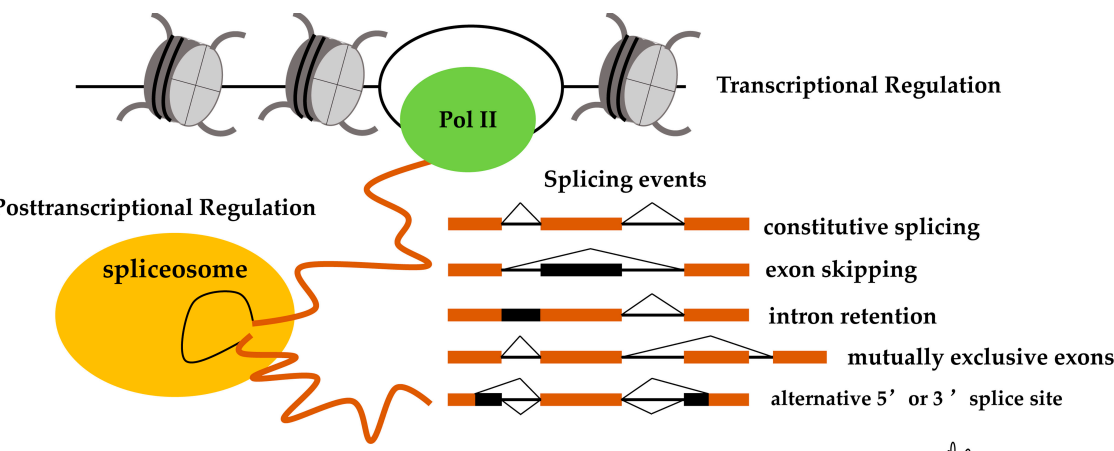

Ambient temperature-mediated flowering: $F L M$

The circadian clock in plants: CCA1, PRR7, PRR9 et al.

Abiotic stress responses: HsfA2, miR400, HAB1 et al.

Biotic stress responses: SNC1, RPS4, RPS6, RPP5 et al.

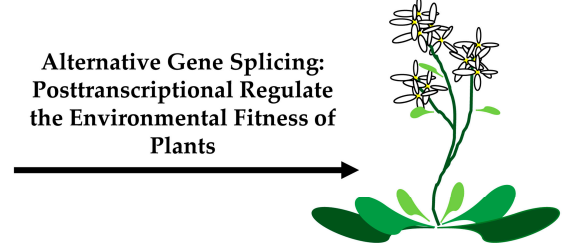

Figure 5. Alternative gene splicing is a novel means of regulating the environmental fitness of plants. Processing of pre-mRNA splicing is initiated during transcription. Splicing is performed by the spliceosome, a large ribonucleoprotein (RNP) complex that assembles around splice sites in the introns of a pre-mRNA molecule and then removes the introns catalytically through sequential phosphodiester transfer reactions. One pre-mRNA generate different mRNA isoforms via alternative splicing events, such as usage of an alternative $3^{\prime}$ or $5^{\prime}$ splicing site, exon skipping, intron retention, and mutually exclusive exons. Given their sessile nature, plants must adapt immediately to environmental changes to ensure their survival. Alternative splicing (AS) plays an important role in the environmental fitness of plants through alternative gene splicing.

Thus far, analyses of AS at the whole-genome level have depended mainly on a high-throughput RNA-Seq approach. AS can enhance the complexity of the transcriptome. However, RNA-Seq data do not distinguish functional from nonfunctional isoforms, and thus may miss functional differences among splice variants.

Plant and animal introns have similar $5^{\prime}$ and $3^{\prime}$ splice sites (GU-AG). However, compared to those in animals, plant introns have their own characteristics in terms of size, nucleotide composition, branch point sequence, and polypyrimidine tract. These differences indicate that some of the initial events in splice site recognition are likely unique to plants (Figure 6) [57,135]. 


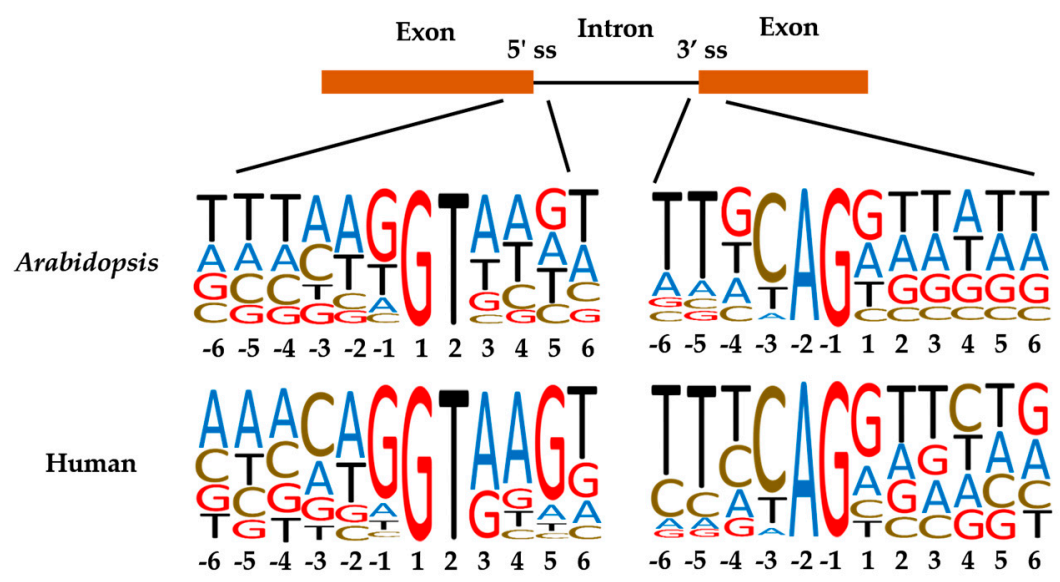

Figure 6. The frequency distribution of nucleotides at the $5^{\prime}$ splice site $\left(5^{\prime} \mathrm{ss}\right)$ and 3 splice site $\left(3^{\prime} \mathrm{ss}\right)$ in Arabidopsis and human. The frequencies of A, T, C, and G at each position are represented by the height of the corresponding letter.

Some components of plant spliceosomes have been identified. Functional analyses of these spliceosomal proteins indicate that the core spliceosomal machinery to conduct splicing is evolutionary conserved between animals and plants (Table 1). However, plants have splicing proteins which do not have homologs in animals, suggesting the existence of the specific recognition of splice site and splicing regulatory mechanisms in plants (Table 1).

Table 1. Plant splicing factors and their human homologs.

\begin{tabular}{ccc}
\hline Plant Splicing Factor & Human Homolog & References \\
\hline U1-70K & U1-70K & {$[60]$} \\
SKIP & SKIP & {$[57]$} \\
SR45 & None & {$[124]$} \\
STIPL1 & TFP11 & {$[58]$} \\
GEMIN2 & GEMIN2 & {$[63]$} \\
SICKLE & None & {$[64]$} \\
MOS4 & SPF27 & {$[108]$} \\
MAC3A/3B & Prp19 & {$[108]$} \\
CDC5 & CDC5L & {$[108]$} \\
ZOP1 & None & {$[120]$} \\
STA1 & Prp6 & {$[121]$} \\
PRP31 & Prp31 & {$[122]$} \\
\hline
\end{tabular}

Acknowledgments: We thank Jessica Habashi for critical reading of the manuscript. This work was supported by grants from the National Natural Science Foundation of China (31671356), and from the Beijing Municipal Government Science Foundation (CIT\&TCD20150102).

Conflicts of Interest: The authors declare no conflict of interest.

\section{References}

1. Sharp, P.A. Split genes and RNA splicing. Cell 1994, 77, 805-815. [CrossRef]

2. Sharp, P.A. The discovery of split genes and RNA splicing. Trends Biochem. Sci. 2005, 30, 279-281. [CrossRef] [PubMed]

3. Moore, M.J.; Proudfoot, N.J. Pre-mRNA processing reaches back to transcription and ahead to translation. Cell 2009, 136, 688-700. [CrossRef] [PubMed]

4. Sharp, P.A. The centrality of RNA. Cell 2009, 136, 577-580. [CrossRef] [PubMed]

5. Fu, X.D.; Manuel Ares, J. Context-dependent control of alternative splicing by RNA-binding proteins. Nat. Rev. Genet. 2014, 15, 689-701. [CrossRef] [PubMed] 
6. Wang, Z.; Burge, C.B. Splicing regulation: From a parts list of regulatory elements to an integrated splicing code. RNA 2008, 14, 802-813. [CrossRef] [PubMed]

7. Deckert, J.; Hartmuth, K.; Boehringer, D.; Behzadnia, N.; Will, C.L.; Kastner, B.; Stark, H.; Urlaub, H.; Lührmann, R. Protein composition and electron microscopy structure of affinity-purified human spliceosomal B complexes isolated under physiological conditions. Mol. Cell. Biol. 2006, 26, 5528-5543. [CrossRef] [PubMed]

8. Jurica, M.S.; Moore, M.J. Pre-mRNA splicing: Awash in a sea of proteins. Mol. Cell 2003, 12, 5-14. [CrossRef]

9. Wahl, M.C.; Will, C.L.; Lührmann, R. The spliceosome: Design principles of a dynamic RNP machine. Cell 2009, 136, 701-718. [CrossRef] [PubMed]

10. Klepikova, A.V.; Kasianov, A.S.; Gerasimov, E.S.; Logacheva, M.D.; Penin, A.A. A high resolution map of the Arabidopsis thaliana developmental transcriptome based on RNA-seq profiling. Plant J. 2016, 88, 1058-1070. [CrossRef] [PubMed]

11. Marquez, Y.; Brown, J.W.S.; Simpson, C.; Barta, A.; Kalyna, M. Transcriptome survey reveals increased complexity of the alternative splicing landscape in Arabidopsis. Genome Res. 2012, 22, 1184-1195. [CrossRef] [PubMed]

12. Reddy, A.S.N.; Marquez, Y.; Kalyna, M.; Barta, A. Complexity of the alternative splicing landscape in plants. Plant Cell 2013, 25, 3657-3683. [CrossRef] [PubMed]

13. McGlincy, N.J.; Smith, C.W. Alternative splicing resulting in nonsense-mediated mRNA decay: What is the meaning of nonsense? Trends Biochem. Sci. 2008, 33, 385-393. [CrossRef] [PubMed]

14. Kalyna, M.; Simpson, C.G.; Syed, N.H.; Lewandowska, D.; Marquez, Y.; Kusenda, B.; Marshall, J.; Fuller, J.; Cardle, L.; McNicol, J.; et al. Alternative splicing and nonsense-mediated decay modulate expression of important regulatory genes in Arabidopsis. Nucleic Acids Res. 2012, 40, 2454-2469. [CrossRef] [PubMed]

15. Syed, N.H.; Kalyna, M.; Marquez, Y.; Barta, A.; and Brown, J.W.S. Alternative splicing in plants-Coming of age. Trends Plant Sci. 2012, 17, 616-623. [CrossRef] [PubMed]

16. Seo, P.J.; Hong, S.Y.; Kim, S.G.; Park, C.M. Competitive inhibition of transcription factors by small interfering peptides. Trends Plant Sci. 2011, 16, 541-549. [CrossRef] [PubMed]

17. Michaels, S.D. Flowering time regulation produces much fruit. Curr. Opin. Plant Biol. 2009, 12, 75-80. [CrossRef] [PubMed]

18. Song, J.; Angel, A.; Howard, M.; Dean, C. Vernalization-A cold induced epigenetic switch. J. Cell Sci. 2012, 125, 3723-3731. [CrossRef] [PubMed]

19. Lee, J.H.; Ryu, H.S.; Chung, K.S.; Posé, D.; Kim, S.; Schmid, M.; Ahn, J.H. Regulation of temperatureresponsive flowering by MADS-box transcription factor repressors. Science 2013, 342, 628-632. [CrossRef] [PubMed]

20. Posé, D.; Verhage, L.; Ott, F.; Yant, L.; Mathieu, J.; Angenent, G.C.; Immink, R.G.H.; Schmid, M. Temperature-dependent regulation of flowering by antagonistic FLM variants. Nature 2013, 503, 414-417. [CrossRef] [PubMed]

21. Amasino, R.M.; Michaels, S.D. The timing of flowering. Plant Physiol. 2010, 154, 516-520. [CrossRef] [PubMed]

22. Ietswaart, R.; Wu, Z.; Dean, C. Flowering time control: Another window to the connection between antisense RNA and chromatin. Trends Genet. 2012, 28, 445-453. [CrossRef] [PubMed]

23. Swiezewski, S.; Liu, F.; Magusin, A.; Dean, C. Cold-induced silencing mediated by long antisense RNA from a Polycomb target. Nature 2009, 462, 799-802. [CrossRef] [PubMed]

24. Wang, Z.; Wu, Z.; Raitskin, O.; Sun, Q.; Dean, C. Antisense-mediated FLC transcriptional repression requires the p-TEFb transcription elongation factor. Proc. Natl. Acad. Sci. USA 2014, 111, 7468-7473. [CrossRef] [PubMed]

25. Marquardt, S.; Raitskin, O.; Wu, Z.; Liu, F.; Sun, Q.; Dean, C. Functional consequences of splicing of the antisense transcript COOLAIR on FLC transcription. Mol. Cell 2014, 54, 156-165. [CrossRef] [PubMed]

26. Li, P.; Tao, Z.; Dean, C. Phenotypic evolution through variation in splicing of the noncoding RNA, COOLAIR. Genes Dev. 2015, 29, 696-701. [CrossRef] [PubMed]

27. Bardou, F.; Ariel, F.; Simpson, C.G.; Romero-Barrios, N.; Laporte, P.; Balzergue, S.; Brown, J.W.; Crespi, M. Long noncoding RNA modulates alternative splicing regulators in Arabidopsis. Dev. Cell 2014, 30, 166-176. [CrossRef] [PubMed]

28. Jiao, Y.; Meyerowitz, E.M. Cell-type specific analysis of translating RNAs in developing flowers reveals new levels of control. Mol. Syst. Biol. 2010, 6, 419. [CrossRef] [PubMed]

29. Balasubramanian, S.; Sureshkumar, S.; Lempe, J.; Weigel, D. Potent induction of Arabidopsis thaliana flowering by elevated growth temperature. PLoS Genet. 2006, 2, e106. [CrossRef] [PubMed] 
30. Balasubramanian, S.; Weigel, D. Temperature induced flowering in Arabidopsis thaliana. Plant Signal. Behav. 2006, 1, 227-228. [CrossRef]

31. Lempe, J.; Balasubramanian, S.; Sureshkumar, S.; Singh, A.; Schmid, M.; Weigel, D. Diversity of flowering responses in wild Arabidopsis thaliana strains. PLoS Genet. 2005, 1, 109-118. [CrossRef]

32. Rosloski, S.M.; Singh, A.; Jali, S.S.; Balasubramanian, S.; Weigel, D.; Grbic, V. Functional analysis of splice variant expression of MADS AFFECTING FLOWERING 2 of Arabidopsis thaliana. Plant Mol. Biol. 2012, 81, 57-69. [CrossRef] [PubMed]

33. McClung, C.R. Plant circadian rhythms. Plant Cell 2006, 18, 792-803. [CrossRef]

34. Harmer, S.L. The circadian system in higher plants. Annu. Rev. Plant Biol. 2009, 60, 357-377. [CrossRef] [PubMed]

35. Schöning, J.C.; Staiger, D. At the pulse of time: Protein interactions determine the pace of circadian clocks. FEBS Lett. 2005, 579, 3246-3252. [CrossRef] [PubMed]

36. Más, P. Circadian clock function in Arabidopsis thaliana: Time beyond transcription. Trends Cell Biol. 2008, 18, 273-281. [CrossRef] [PubMed]

37. Herrero, E.; Davis, S.J. Time for a nuclear meeting: Protein trafficking and chromatin dynamics intersect in the plant circadian system. Mol. Plant 2012, 5, 554-565. [CrossRef]

38. McClung, C.R. The genetics of plant clocks. Adv. Genet. 2011, 74, 105-139. [PubMed]

39. Alabadi, D.; Oyama, T.; Yanovsky, M.J.; Harmon, F.G.; Mas, P.; Kay, S.A. Reciprocal regulation between TOC1 and LHY /CCA1 within the Arabidopsis circadian clock. Science 2001, 293, 880-883. [CrossRef] [PubMed]

40. Green, R.M.; Tobin, E.M. The role of CCA1 and LHY in the plant circadian clock. Dev. Cell 2002, 2, 516-518. [CrossRef]

41. Gendron, J.M.; Pruneda-Paz, J.L.; Doherty, C.J.; Gross, A.M.; Kang, S.E.; Kay, S.A. Arabidopsis circadian clock protein, TOC1, is a DNA-binding transcription factor. Proc. Natl. Acad. Sci. USA 2012, 109, 3167-3172. [CrossRef] [PubMed]

42. Huang, W.; Perez-Garcia, P.; Pokhilko, A.; Millar, A.J.; Antoshechkin, I.; Riechmann, J.L.; Mas, P. Mapping the core of the Arabidopsis circadian clock defines the network structure of the oscillator. Science 2012, 336, 75-79. [CrossRef] [PubMed]

43. Pokhilko, A.; Fernandez, A.P.; Edwards, K.D.; Southern, M.M.; Halliday, K.J.; Millar, A.J. The clock gene circuit in Arabidopsis includes a repressilator with additional feedback loops. Mol. Syst. Biol. 2012, 8, 574. [CrossRef] [PubMed]

44. Farre, E.M.; Harmer, S.L.; Harmon, F.G.; Yanovsky, M.J.; Kay, S.A. Overlapping and distinct roles of PRR7 and PRR9 in the Arabidopsis circadian clock. Curr. Biol. 2005, 15, 47-54. [CrossRef] [PubMed]

45. Nakamichi, N.; Kiba, T.; Henriques, R.; Mizuno, T.; Chua, N.H.; Sakakibara, H. PSEUDO-RESPONSE REGULATORS 9, 7, and 5 are transcriptional repressors in the Arabidopsis circadian clock. Plant Cell 2010, 22, 594-605. [CrossRef]

46. Pruneda-Paz, J.L.; Kay, S.A. An expanding universe of circadian networks in higher plants. Trends Plant Sci. 2010, 15, 259-265. [CrossRef] [PubMed]

47. Helfer, A.; Nusinow, D.A.; Chow, B.Y.; Gehrke, A.R.; Bulyk, M.L.; Kay, S.A. LUX ARRHYTHMO encodes a night time repressor of circadian gene expression in the Arabidopsis core clock. Curr. Biol. 2011, 21, 126-133. [CrossRef] [PubMed]

48. Herrero, E.; Kolmos, E.; Bujdoso, N.; Yuan, Y.; Wang, M.; Berns, M.C.; Uhlworm, H.; Coupland, G.; Saini, R.; Jaskolski, M.; et al. EARLY FLOWERING4 recruitment of EARLY FLOWERING3 in the nucleus sustains the Arabidopsis circadian clock. Plant Cell 2012, 24, 428-443. [CrossRef] [PubMed]

49. Filichkin, S.A.; Priest, H.D.; Givan, S.A.; Shen, R.; Bryant, D.W.; Fox, S.E.; Wong, W.K.; Mockler, T.C. Genome-wide mapping of alternative splicing in Arabidopsis thaliana. Genome Res. 2010, 20, 45-58. [CrossRef] [PubMed]

50. Seo, P.J.; Park, M.J.; Lim, M.H.; Kim, S.G.; Lee, M.; Baldwin, I.T.; Park, C.M. A self-regulatory circuit of CIRCADIANCLOCK-ASSOCIATED1 underlies the circadian clock regulation of temperature responses in Arabidopsis. Plant Cell 2011, 24, 2427-2442. [CrossRef] [PubMed]

51. Daniel, X.; Sugano, S.; Tobin, E.M. CK2 phosphorylation of CCA1 is necessary for its circadian oscillator function in Arabidopsis. Proc. Natl. Acad. Sci. USA 2004, 101, 3292-3297. [CrossRef] [PubMed] 
52. Lu, S.X.; Knowles, S.M.; Andronis, C.; Ong, M.S.; Tobin, E.M. CIRCADIAN CLOCK ASSOCIATED1 and LATE ELONGATED HYPOCOTYL function synergistically in the circadian clock of Arabidopsis. Plant Physiol. 2009, 150, 834-843. [CrossRef] [PubMed]

53. Filichkin, S.A.; Cumbie, J.S.; Dharmawardhana, J.P.; Jaiswal, P.; Chang, J.H.; Palusa, S.G.; Reddy, A.S.; Megraw, M.; Mockler, T.C. Environmental stresses modulate abundance and timing of alternatively spliced circadian transcripts in Arabidopsis. Mol. Plant 2015, 8, 207-227. [CrossRef] [PubMed]

54. Sanchez, S.E.; Petrillo, E.; Beckwith, E.J.; Zhang, X.; Rugnone, M.L.; Hernando, C.E.; Cuevas, J.C.; GodoyHerz, M.A.; Depetris-Chauvin, A.; Simpson, C.G.; et al. A methyl transferase links the circadian clock to the regulation of alternative splicing. Nature 2010, 468, 112-116. [CrossRef] [PubMed]

55. Deng, X.; Gu, L.; Liu, C.; Lu, T.; Lu, F.; Lu, Z.; Cui, P.; Pei, Y.; Wang, B.; Hu, S.; et al. Arginine methylation mediated by the Arabidopsis homolog of PRMT5 is essential for proper pre-mRNA splicing. Proc. Natl. Acad. Sci. USA 2010, 107, 19114-19119. [CrossRef] [PubMed]

56. Hong, S.; Song, H.R.; Lutz, K.; Kerstetter, R.A.; Michael, T.P.; McClung, C.R. Type II protein arginine methyltransferase 5 (PRMT5) is required for circadian period determination in Arabidopsis thaliana. Proc. Natl. Acad. Sci. USA 2010, 107, 21211-21216. [CrossRef] [PubMed]

57. Wang, X.; Wu, F.; Xie, Q.; Wang, H.; Wang, Y.; Yue, Y.; Gahura, O.; Ma, S.; Liu, L.; Cao, Y.; et al. SKIP is a component of the spliceosome linking alternative splicing and the circadian clock in Arabidopsis. Plant Cell 2012, 24, 3278-3295. [CrossRef] [PubMed]

58. Jones, M.A.; Williams, B.A.; McNicol, J.; Simpson, C.G.; Brown, J.W.; Harmer, S.L. Mutation of Arabidopsis spliceosomal timekeeper locus1 causes circadian clock defects. Plant Cell 2012, 24, 4066-4082. [CrossRef] [PubMed]

59. Figueroa, J.D.; Hayman, M.J. The human Ski-interacting protein functionally substitutes for the yeast PRP45 gene. Biochem. Biophys. Res. Commun. 2004, 319, 1105-1109. [CrossRef] [PubMed]

60. Golovkin, M.; Reddy, A.S. Structure and expression of a plant U1 snRNP 70K gene: Alternative splicing of U1 snRNP 70K pre-mRNAs produces two different transcripts. Plant Cell 1996, 8, 1421-1435. [CrossRef] [PubMed]

61. Day, I.S.; Golovkin, M.; Palusa, S.G.; Link, A.; Ali, G.S.; Thomas, J.; Richardson, D.N.; Reddy, A.S. Interactions of SR45, an SR-like protein, with spliceosomal proteins and an intronic sequence: Insights into regulated splicing. Plant J. Cell Mol. Biol. 2012, 71, 936-947. [CrossRef] [PubMed]

62. Li, Y.; Xia, C.; Feng, J.; Yang, D.; Wu, F.; Cao, Y.; Li, L.; Ma, L. The SNW domain of SKIP is required for itsintegration into the spliceosome and its interaction with the Pall complex in Arabidopsis. Mol. Plant 2016, 7, 1040-1050. [CrossRef] [PubMed]

63. Schlaen, R.G.; Mancini, E.; Sanchez, S.E.; Perezsantángelo, S.; Rugnone, M.L.; Simpson, C.G.; Brown, J.W.; Zhang, X.; Chernomoretz, A.; Yanovsky, M.J. The spliceosome assembly factor GEMIN2 attenuates the effects of temperature on alternative splicing and circadian rhythms. Proc. Natl. Acad. Sci. USA 2015, 112, 9382-9387. [CrossRef] [PubMed]

64. Marshall, C.M.; Tartaglio, V.; Duarte, M.; Harmon, F.G. The Arabidopsis sickle mutant exhibits altered circadian clock responses to cool temperatures and temperature-dependent alternative splicing. Plant Cell 2016, 10, 2560-2575. [CrossRef] [PubMed]

65. Hegele, A.; Kamburov, A.; Grossmann, A.; Sourlis, C.; Wowro, S.; Weimann, M.; Will, C.L.; Pena, V.; Lührmann, R.; Stelzl, U. Dynamic protein-protein interaction wiring of the human spliceosome. Mol. Cell 2012, 45, 567-580. [CrossRef] [PubMed]

66. Xiong, L.; Schumaker, K.S.; Zhu, J.K. Cell signaling during cold, drought, and salt stress. Plant Cell 2002, 14, S165-S183. [PubMed]

67. Zhu, J.K. Salt and drought stress signal transduction in plants. Annu. Rev. Plant Biol. 2002, 53, $247-273$. [CrossRef] [PubMed]

68. Munns, R.; Tester, M. Mechanisms of salinity tolerance. Annu. Rev. Plant Biol. 2008, 59, 651-681. [CrossRef] [PubMed]

69. Von Koskull-Döring, P.; Scharf, K.D.; Nover, L. The diversity of plant heat stress transcription factors. Trends Plant Sci. 2007, 12, 452-457. [CrossRef] [PubMed]

70. Sugio, A.; Dreos, R.; Aparicio, F.; Maule, A.J. The cytosolic protein response as a subcomponent of the wider heat shock response in Arabidopsis. Plant Cell 2009, 21, 642-654. [CrossRef] [PubMed] 
71. Liu, J.; Sun, N.; Liu, M.; Liu, J.; Du, B.; Wang, X.; Qi, X. An autoregulatory loop controlling Arabidopsis HsfA2 expression: Role of heat shock-induced alternative splicing. Plant Physiol. 2013, 162, 512-521. [CrossRef] [PubMed]

72. Torres, M.A.; Dangl, J.L.; Jones, J.D. Arabidopsis gp91phox homologues AtrbohD and AtrbohF are required for accumulation of reactive oxygen intermediates in the plant defense response. Proc. Natl. Acad. Sci. USA 2002, 99, 517-522. [CrossRef]

73. Torres, M.A.; Jones, J.D.; Dangl, J.L. Pathogen-induced, NADPH oxidase-derived reactive oxygen intermediates suppress spread of cell death in Arabidopsis thaliana. Nat. Genet. 2005, 37, 1130-1134. [CrossRef] [PubMed]

74. Lin, F.; Zhang, Y.; Jiang, M.Y. Alternative splicing and differential expression of two transcripts of nicotine adenine dinucleotide phosphate oxidase B gene from Zea mays. J. Integr. Plant Biol. 2009, 51, 287-298. [CrossRef] [PubMed]

75. Matsukura, S.; Mizoi, J.; Yoshida, T.; Todaka, D.; Ito, Y.; Maruyama, K.; Shinozaki, K.; Yamaguchi-Shinozaki, K. Comprehensive analysis of rice DREB2-type genes that encode transcription factors involved in the expression of abiotic stress-responsive genes. Mol. Genet. Genom. 2010, 283, 185-196. [CrossRef] [PubMed]

76. Xue, G.P.; Loveridge, C.W. HvDRF1 is involved in abscisic acid-mediated gene regulation in barley and produces two forms of AP2 transcriptional activators, interacting preferably with a CT-rich element. Plant J. 2004, 37, 326-339. [CrossRef] [PubMed]

77. Egawa, C.; Kobayashi, F.; Ishibashi, M.; Nakamura, T.; Nakamura, C.; Takumi, S. Differential regulation of transcript accumulation and alternative splicing of a DREB2 homolog under abiotic stress conditions in common wheat. Genes Genet. Syst. 2006, 81, 77-91. [CrossRef] [PubMed]

78. Qin, F.; Kakimoto, M.; Sakuma, Y.; Maruyama, K.; Osakabe, Y.; Tran, L.S.; Shinozaki, K.; Yamaguchi-Shinozaki, K. Regulation and functional analysis of ZmDREB2A in response to drought and heat stresses in Zea mays L. Plant J. 2007, 50, 54-69. [CrossRef] [PubMed]

79. Yan, K.; Liu, P.; Wu, C.A.; Yang, G.D.; Xu, R.; Guo, Q.H.; Huang, J.G.; Zheng, C.C. Stress-induced alternative splicing provides a mechanism for the regulation of microRNA processing in Arabidopsis thaliana. Mol. Cell 2012, 48, 521-531. [CrossRef] [PubMed]

80. Wang, Z.; Ji, H.; Yuan, B.; Wang, S.; Su, C.; Yao, B.; Zhao, H.; Li, X. ABA signalling is fine-tuned by antagonistic HAB1 variants. Nat. Commun. 2015, 6, 1-12. [CrossRef] [PubMed]

81. Zhan, X.; Qian, B.; Cao, F.; Wu, W.; Yang, L.; Guan, Q.; Gu, X.; Wang, P.; Okusolubo, T.A.; Dunn, S.L.; et al. An Arabidopsis PWI and RRM motif-containing protein is critical for pre-mRNA splicing and ABA responses. Nat. Commun. 2015, 6, 8139. [CrossRef] [PubMed]

82. Ali, G.S.; Palusa, S.G.; Golovkin, M.; Prasad, J.; Manley, J.L.; Reddy, A.S.N. Regulation of plant developmental processes by a novel splicing factor. PLoS ONE. 2007, 2, e471. [CrossRef] [PubMed]

83. Carvalho, R.F.; Carvalho, S.D.; Duque, P. The plant specific SR45 protein negatively regulates glucose and ABA signaling during early seedling development in Arabidopsis. Plant Physiol. 2010, 154, 772-783. [CrossRef] [PubMed]

84. Carvalho, R.F.; Szakonyi, D.; Simpson, C.G.; Barbosa, I.C.; Brown, J.W.; Baena-González, E.; Duque, P. The Arabidopsis SR45 splicing factor, a negative regulator of sugar signaling, modulates SNF1-related protein kinase 1 stability. Plant Cell 2016, 28, 1910-1925. [CrossRef]

85. Palusa, S.G.; Ali, G.S.; Reddy, A.S. Alternative splicing of pre-mRNAs of Arabidopsis serine/arginine-rich proteins: Regulation by hormones and stresses. Plant J. 2007, 49, 1091-1107. [CrossRef] [PubMed]

86. Zhang, X.N.; Mount, S.M. Two alternatively spliced isoforms of the Arabidopsis SR45 protein have distinct roles during normal plant development. Plant Physiol. 2009, 150, 1450-1458. [CrossRef] [PubMed]

87. Zhang, L.H. Quorum quenching and proactive host defense. Trends Plant Sci. 2003, 8, 238-244. [CrossRef]

88. Deyoung, B.J.; Innes, R.W. Plant NBS-LRR proteins in pathogen sensing and host defense. Nat. Immunol. 2006, 7, 1243-1249. [CrossRef] [PubMed]

89. Staiger, D.; Brown, J.W.S. Alternative splicing at the intersection of biological timing, development, and stress responses. Plant Cell 2013, 25, 3640-3656. [CrossRef] [PubMed]

90. Traut, T.W. The functions and consensus motifs of nine types of peptide segments that form different types of nucleotide-binding sites. Eur. J. Biochem. 1994, 222, 9-19. [CrossRef] [PubMed]

91. Kobe, B.; Deisenhofer, J. The leucine-rich repeat: A versatile binding motif. Trends Biochem. Sci. 1994, 19, 415-421. [CrossRef]

92. Ellis, J.G.; Lawrence, G.J.; Luck, J.E.; Dodds, P.N. Identification of regions in alleles of the flax rust resistance gene $\mathrm{L}$ that determine differences in gene-for-gene specificity. Plant Cell 1999, 11, 495-506. [CrossRef] [PubMed] 
93. Leister, R.T.; Katagiri, F. A resistance gene product of the nucleotide binding site-Leucine rich repeats class can form a complex with bacterial avirulence proteins in vivo. Plant J. 2000, 22, 345-354. [CrossRef] [PubMed]

94. Jia, Y.; McAdams, S.A.; Bryan, G.T.; Hershey, H.P.; Valent, B. Direct interaction of resistance gene and avirulence gene productsconfers rice blast resistance. EMBO J. 2000, 19, 4004-4014. [CrossRef] [PubMed]

95. Whitham, S.; Dinesh-Kumar, S.P.; Choi, D.; Hehl, R.; Corr, C.; Baker, B. The product of the tobacco mosaic virus resistance gene N: Similarity to toll and the interleukin-1 receptor. Cell 1994, 78, 1101-1115. [CrossRef]

96. Kim, S.H.; Kwon, S.I.; Saha, D.; Anyanwu, N.C.; Gassmann, W. Resistance to the Pseudomonas syringae effector HopA1 is governed by the TIR-NBS-LRR protein RPS6 and is enhanced by mutations in SRFR1. Plant Physiol. 2009, 150, 1723-1732. [CrossRef] [PubMed]

97. Borhan, M.H.; Holub, E.B.; Beynon, J.L.; Rozwadowski, K.; Rimmer, S.R. The Arabidopsis TIR-NB-LRR gene RAC1 confers resistance to Albugo candida (white rust) and is dependent on EDS1 but not PAD4. Mol. Plant Microbe Interact. 2004, 17, 711-719. [CrossRef] [PubMed]

98. Parker, J.E.; Coleman, M.J.; Szabo, V.; Frost, L.N.; Schmidt, R.; van der Biezen, E.A.; Moores, T.; Dean, C.; Daniels, M.J.; Jones, J.D. The Arabidopsis downy mildew resistance gene RPP5 shares similarity to the toll and interleukin-1 receptors with N and L6. Plant Cell 1997, 9, 879-894. [CrossRef] [PubMed]

99. Gassmann, W.; Hinsch, M.E.; Staskawicz, B.J. The Arabidopsis RPS4 bacterial-resistance gene is a member of the TIR-NBS-LRR family of disease-resistance genes. Plant J. 1999, 20, 265-277. [CrossRef] [PubMed]

100. Yi, H.; Richards, E.J. A cluster of disease resistance genes in Arabidopsis is coordinately regulated by transcriptional activation and RNA silencing. Plant Cell 2007, 19, 2929-2939. [CrossRef] [PubMed]

101. Schornack, S.; Ballvora, A.; Gurlebeck, D.; Peart, J.; Baulcombe, D.; Ganal, M.; Baker, B.; Bonas, U.; Lahaye, T. The tomato resistance protein Bs4 is a predicted non-nuclear TIR-NB-LRR protein that mediates defense responses to severely truncated derivatives of AvrBs4 and overexpressed AvrBs3. Plant J. 2004, 37, 46-60. [CrossRef] [PubMed]

102. Dinesh-Kumar, S.P.; Baker, B.J. Alternatively spliced N resistance gene transcripts: Their possible role in tobacco mosaic virus resistance. Proc. Natl. Acad. Sci. USA 2000, 97, 1908-1913. [CrossRef] [PubMed]

103. Zhang, X.C.; Gassmann, W. RPS4-mediated disease resistance requires the combined presence of RPS4 transcripts with full-length and truncated open reading frames. Plant Cell 2003, 15, 2333-2342. [CrossRef] [PubMed]

104. Mastrangelo, A.M.; Marone, D.; Laido, G.; De Leonardis, A.M.; De Vita, P. Alternative splicing: Enhancing ability to cope with stress via transcriptome plasticity. Plant Sci. 2012, 185, 40-49. [CrossRef] [PubMed]

105. Palma, K.; Zhao, Q.; Cheng, Y.T.; Bi, D.; Monaghan, J.; Cheng, W.; Zhang, Y.; Li, X. Regulation of plant innate immunity by three proteins in a complex conserved across the plant and animal kingdoms. Genes Dev. 2007, 21, 1484-1493. [CrossRef] [PubMed]

106. Hogg, R.; McGrail, J.C.; Keefe, R.T. The function of the NineTeen Complex (NTC) in regulating spliceosome conformations and fidelity during pre-mRNA splicing. Biochem. Soc. Trans. 2010, 38, 1110-1115. [CrossRef] [PubMed]

107. Xu, F.; Xu, S.; Wiermer, M.; Zhang, Y.; Li, X. The cyclin L homolog MOS12 and the MOS4-associated complex are required for the proper splicing of plant resistance genes. Plant J. 2012, 70, 916-928. [CrossRef] [PubMed]

108. Monaghan, J.; Xu, F.; Xu, S.; Zhang, Y.; Li, X. Two putative RNA-binding proteins function with unequal genetic redundancy in the MOS4-associated complex. Plant Physiol. 2010, 154, 1783-1793. [CrossRef] [PubMed]

109. Koncz, C.; Dejong, F.; Villacorta, N.; Szakonyi, D.; Koncz, Z. The spliceosome-activating complex: Molecular mechanisms underlying the function of a pleiotropic regulator. Front. Plant Sci. 2012, 3, 9. [CrossRef] [PubMed]

110. He, Y.; Doyle, M.R.; Amasino, R.M. PAF1-complex mediated histone methylation of FLOWERING LOCUS C chromatin is required or the vernalization- responsive, winter-annual habit in Arabidopsis. Genes Dev. 2004, 18, 2774-2784. [CrossRef] [PubMed]

111. Cao, Y.; Wen, L.; Wang, Z.; Ma, L. SKIP interacts with the Paf1 complex to regulate flowering via the activation of FLC, transcription in Arabidopsis. Mol. Plant 2015, 8, 1816-1819. [CrossRef] [PubMed]

112. Kowalik, K.M.; Shimada, Y.; Flury, V.; Stadler, M.B.; Batki, J.; Buhler, M. The Paf1 complex represses small-RNA-mediated epigenetic gene silencing. Nature 2015, 520, 248-252. [CrossRef] [PubMed] 
113. Tomson, B.N.; Arndt, K.M. The many roles of the conserved eukaryotic Paf1 complex in regulating transcription, histone modifications, and disease states. Biochim. Biophys. Acta 2013, 1829, 116-126. [CrossRef] [PubMed]

114. Slotkin, R.K.; Martienssen, R. Transposable elements and the epigenetic regulation of the genome. Nat. Rev. Genet. 2007, 8, 272-285. [CrossRef] [PubMed]

115. Matzke, M.; Kanno, T.; Daxinger, L.; Huettel, B.; Matzke, A.J. RNA-mediated chromatin-based silencing in plants. Curr. Opin. Cell Biol. 2009, 21, 367-376. [CrossRef] [PubMed]

116. Law, J.A.; Jacobsen, S.E. Establishing, maintaining and modifying DNA methylation patterns in plants and animals. Nat. Rev. Genet. 2010, 11, 204-220. [CrossRef] [PubMed]

117. Gong, Z.; Morales-Ruiz, T.; Ariza, R.R.; Roldán-Arjona, T.; David, L.; Zhu, J.K. ROS1, a repressor of transcriptional gene silencing in Arabidopsis, encodes a DNA glycosylase/lyase. Cell 2002, 111, 803-814. [CrossRef]

118. Liu, J.; Bai, G.; Zhang, C.; Chen, W.; Zhou, J.; Zhang, S.; Chen, Q.; Deng, X.; He, X.J.; Zhu, J.K. An atypical component of RNA-directed DNA methylation machinery has both DNA methylation-dependent and -independent roles in locus-specific transcriptional gene silencing. Cell Res. 2011, 21, 1691-1700. [CrossRef] [PubMed]

119. Ausin, I.; Greenberg, M.V.; Li, C.F.; Jacobsen, S.E. The splicing factor SR45 affects the RNA-directed DNA methylation pathway in Arabidopsis. Epigenetics 2012, 7, 29-33. [CrossRef] [PubMed]

120. Zhang, C.J.; Zhou, J.X.; Liu, J.; Ma, Z.Y.; Zhang, S.W.; Dou, K.; Huang, H.W.; Cai, T.; Liu, R.; Zhu, J.K.; et al. The splicing machinery promotes RNA-directed DNA methylation and transcriptional silencing in Arabidopsis. EMBO J. 2013, 32, 1128-1140. [CrossRef] [PubMed]

121. Dou, K.; Huang, C.F.; Ma, Z.Y.; Zhang, C.J.; Zhou, J.X.; Huang, H.W.; Cai, T.; Tang, K.; Zhu, J.K.; He, X.J. The PRP6-like splicing factor STA1 is involved in RNA-directed DNA methylation by facilitating the production of Pol V-dependent scaffold RNAs. Nucleic Acids Res. 2013, 41, 8489-8502. [CrossRef] [PubMed]

122. Du, J.L.; Zhang, S.W.; Huang, H.W.; Cai, T.; Li, L.; Chen, S.; He, X.J. The splicing factor PRP31 is involved in transcriptional gene silencing and stress response in Arabidopsis. Mol. Plant 2015, 8, 1053-1068. [CrossRef] [PubMed]

123. Huang, C.F.; Miki, D.; Tang, K.; Zhou, H.R.; Zheng, Z.; Chen, W.; Ma, Z.Y.; Yang, L.; Zhang, H.; Liu, R.; et al. A Pre-mRNA splicing factor is required for RNA-directed DNA methylation in Arabidopsis. PLoS Genet. 2013, 9, e1003779. [CrossRef] [PubMed]

124. Golovkin, M.; Reddy, A.S. An SC35-like protein and a novel serine/arginine-rich protein interact with Arabidopsis U1-70K protein. J. Biol. Chem. 1999, 274, 36428-36438. [CrossRef] [PubMed]

125. Zhuang, Y.; Weiner, A.M. A compensatory base change in U1 snRNA suppresses a $5^{\prime}$ splice site mutation. Cell 1986, 46, 827-835. [CrossRef]

126. Kohtz, J.D.; Jamison, S.F.; Will, C.L.; Zuo, P.; Lührmann, R.; Garcia-Blanco, M.A.; Manley, J.L. Protein-protein interactions and 5'-splice-site recognition in mammalian mRNA precursors. Nature 1994, 368, 119-124. [CrossRef] [PubMed]

127. Wu, S.; Romfo, C.M.; Nilsen, T.W.; Green, M.R. Functional recognition of the $3^{\prime}$ splice site AG by the splicing factor U2A.F.35. Nature 1999, 402, 832-835. [CrossRef] [PubMed]

128. Zhang, X.N.; Mo, C.; Garrett, W.M.; Cooper, B. Phosphothreonine 218 is required for the function of SR45.1 in regulating flower petal development in Arabidopsis. Plant Signal. Behav. 2014, 9, e29134. [CrossRef] [PubMed]

129. Stankovic, N.; Schloesser, M.; Joris, M.; Sauvage, E.; Hanikenne, M.; Motte, P. Dynamic distribution and interaction of the Arabidopsis SRSF1 subfamily splicing factors. Plant Physiol. 2016, 170, 1000-1013. [CrossRef] [PubMed]

130. Feng, J.; Li, J.; Gao, Z.; Lu, Y.; Yu, J.; Zheng, Q.; Yan, S.; Zhang, W.; He, H.; Ma, L.; et al. SKIP confers osmotic tolerance during salt stress by controlling alternative gene splicing in Arabidopsis. Mol. Plant 2015, 8 , 1038-1052. [CrossRef] [PubMed]

131. Baldwin, K.L.; Dinh, E.M.; Hart, B.M.; Masson, P.H. CACTIN is an essential nuclear protein in Arabidopsis and may be associated with the eukaryotic spliceosome. FEBS Lett. 2013, 587, 873-879. [CrossRef] [PubMed]

132. Schwerk, C.; Prasad, J.; Degenhardt, K.; Erdjument-Bromage, H.; White, E.; Tempst, P.; Kidd, V.J.; Manley, J.L.; Lahti, J.M.; Reinberg, D. Asap, a novel protein complex involved in RNA processing and apoptosis. Mol. Cell. Biol. 2003, 23, 2981-2990. [CrossRef] [PubMed]

133. Qüesta, J.I.; Song, J.; Geraldo, N.; An, H.; Dean, C. Arabidopsis transcriptional repressor val1 triggers polycomb silencing at FLC during vernalization. Science 2016, 353, 485-488. [CrossRef] [PubMed] 
134. Xing, D.; Wang, Y.; Hamilton, M.; Benhur, A.; Reddy, A.S. Transcriptome-wide identification of RNA targets of Arabidopsis serine/arginine-rich45 uncovers the unexpected roles of this RNA binding protein in RNA processing. Plant Cell 2015, 27, 3294. [CrossRef] [PubMed]

135. Reddy, A.S. Alternative splicing of pre-messenger RNAs in plants in the genomic era. Annu. Rev. Plant Biol. 2007, 58, 267-294. [CrossRef] [PubMed] 